Journal of Community Based Environmental Engineering and Management, 2019, Vol. 3, No. 1: 1-8

\title{
SANITASI BERBASIS MASYARAKAT DI PESANTREN PUTRI AL-ITTIHAD, KABUPATEN CIANJUR
}

\author{
Astri Widiastuti Hasbiah*, Deni Rusmaya, Damar Apriani DQ \\ Program Studi Teknik Lingkungan, Universitas Pasundan
}

\begin{abstract}
Abstrak
Pemenuhan fasilitas sanitasi merupakan salah satu kegiatan yang penting dalam kehidupan domestik manusia. Sebagai asrama yang ditempati oleh santri, Pesantren Putri Al-Ittihad harus menjaga fasilitas sanitasinya guna menjaga kesehatan para santri putrinya. Penelitian ini bertujuan untuk mengidentifikasi kondisi sanitasi di pesantren tersebut serta menganalisis kebutuhan air minum dan fasilitas sanitasi yang diperlukan dalam kegiatan keseharian santrinya. Metode yang digunakan dalam analisis ini adalah pengamatan lapangan serta wawancara kepada 95 santri sebagai responden. Hasil penelitian menunjukkan bahwa secara kualitas, air bersih masih dapat diterima santri karena tidak berbau, tidak berasa dan tidak berwarna, namun secara kuantitas masih belum memenuhi dan perlu ditambah dari sumber air berupa mata air yang terletak di sekitar pesantren. Pengelolaan sampah belum optimal karena sampah organik belum dimanfaatkan. Jika kegiatan pengomposan dilakukan, maka perlu rumah pengomposan dengan luas $13,5 \mathrm{~m}^{3}$. Terdapat 137 ruang mandi yang disediakan untuk 1785 santri. Berdasarkan ketentuan dan perhitungan, jumlah MCK seharusnya minimal 179 ruang. Fasilitas dan teknologi lain yang perlu disediakan adalah lubang biopori untuk mengatasi genangan dan septic tank untuk mengolah air limbah.
\end{abstract}

Kata kunci: Pesantren, fasilitas sanitasi, santri putri

\section{Pendahuluan}

Sebagaimana sanitasi rumah, sanitasi Pondok Pesantren (Ponpes) pada dasarnya adalah usaha kesehatan masyarakat yang menitik beratkan pada pengawasan terhadap struktur fisik, dimana orang menggunakannya sebagai tempat berlindung yang mempengaruhi derajat kesehatan manusia. Sarana sanitasi tersebut adalah konstruksi bangunan, sarana pembuangan sampah, sarana pembuangan kotoran manusia, dan penyediaan air bersih (Sidhi, Raharjo, \& Dewant, 2016).

\footnotetext{
${ }^{*}$ Penulis Korespondensi:

E-mail: astrihasbiah@unpas.ac.id

Diterima pertama kali: 14 Desember 2018

Direvisi : 30 Desember 2018

Disetujui untuk publikasi: 1 Februari 2019
}

Pondok pesantren adalah sebuah asrama pendidikan Islam di mana siswa belajar dan tinggal bersama di bawah bimbingan guru/ustadz Ponpes, selain dikenal sebagai tempat belajar santri dan santriwati dalam mendalami ilmu agama Islam, namun Ponpes selama ini juga dikenal bermasalah dari aspek air bersih dan sanitasi. Berbagai penyakit berbasis lingkungan yang umum sering menjadi masalah di Ponpes disebabkan oleh lingkungan yang kurang sehat di Pondok Pesantren (Adriansyah, 2017).

Pondok Pesantren Al-Ittihad adalah salah satu lembaga pendidikan yang terdiri dari SMP, SMA Plus, dan SMK Terpadu. Al-Ittihad merupakan Pondok Pesantren modern yang terletak di Kabupaten Cianjur. Dengan jumlah 
Santri sebanyak 3247 yang terbagi atas 1462 santri putera dan 1785 santri puteri.

Berdasarkan hasil studi pendahuluan yang dilakukan, Pondok Pesantren Al-Ittihad Kabupaten Cianjur untuk kawasan putri memiliki kondisi sanitasi yang masih kurang baik, diantaranya kondisi sarana air bersih dan air minum, ketersediaan MCK (Mandi Cuci Kakus), pengolahan limbah dan tempat pembuangan sampah. Hal ini, akibat dari ketidakseimbangan kualitas dan kuantitas fasilitas sanitasi lingkungan Pondok Pesantren. Berdasarkan kondisi tersebut diatas, dalam studi ini direncanakan pengembangan unit sarana dan prasarana sanitasi.

Tujuan studi ini adalah untuk mengetahui kondisi sanitasi secara eksisiting dan memberikan saran terkait perencanaan sanitasi yang baik di pondok pesantren Al Ittihad.

\section{Metodologi Penelitian}

\section{Lokasi Penelitian}

Pondok Pesantren Al-Ittihad terletak di Desa/Kelurahan Bojong RT 11 RW 01 Kecamata Karangtengah Kabupaten Cianjur, tepatnya Jalan Raya Bandung Bojong Karangtengah. Secara geografis, letak Pondok Pesantren Al-Ittihad sangat strategis dan mudah diakses karena berada tidak jauh dari Terminal Rawabango dan berada di jalur utama jalan raya antara Bandung dan Sukabumi, Bogor dan Jakarta.

Penelitian ini dibatasi hanya pada kawasan puteri. Dan akan dilakukan identifikasi ketersediaan fasilitas sanitasi di pondok pesantren yang meliputi air bersih, mandi cuci kakus (MCK), sarana pembuangan sampah, sarana pembuangan air limbah dan drainase.

\section{Sumber Data}

Data yang digunakan dalam penelitian ini berdasarkan sumber data yang terbagi atas dua jenis yaitu sumber primer dan sumber sekunder. a. Data primer diperoleh dari hasil wawancara serta dari hasil pengisian kuesioner oleh responden santri putri.

b. Data sekunder yang digunakan dalam penelitian ini diambil pengelola pondok pesantren Al Ittihad.

Data primer diambil berdasarkan simple random sampling yaitu pengambilan sampel kepada populasi responden di mana pemilihan sampel sederhana secara acak tanpa memperhatikan strata yang ada di dalam populasi tersebut. Rumus Slovin digunakan untuk menentukan ukuran responden (Pradana \& Reventiary, 2016):

$$
\mathrm{n}=\frac{N}{1+N e^{2}}
$$

Dimana :

n : ukuran sampel

$\mathrm{N}$ : ukuran populasi

e : nilai kritis (batas penelitian) yang diinginkan (persen kelonggaran ketidaktelitian karena kesalahan pengambilan sampel populasi)

Diketahu jumlah santri untuk jenjang pendidikan SMP, SMA dan SMK adalah sebagai berikut:

Jumlah Santri SMP $\quad: 828$

Jumlah Santri SMA : 356

Jumlah Santri SMK : 601

Jumlah Santri Putri : 1785

Pada perencanaan ini digunakan tingkat error sebesar $10 \%$. Hasil perhitungan jumlah sampel:

$\mathrm{n}=\frac{1785}{1+1785 \times 0,1^{2}}=94,69 \approx 95$

- Jumlah responden SMP: SMP : $\frac{\mathbf{8 2 8}}{\mathbf{1 7 8 5}}=\mathbf{0}, \mathbf{4 6} \times 95=43,7 \approx 44$ Santri

- Jumlah responden SMA: SMA : $\frac{\mathbf{3 5 6}}{\mathbf{1 7 8 5}}=\mathbf{0}, \mathbf{1 9}$ X $95=18,05 \approx 19$ Santri

- Jumlah responden SMK:

SMK $: \frac{\mathbf{6 0 1}}{\mathbf{1 7 8 5}}=\mathbf{0}, 33$ X $95=1,35 \approx 32$ Santri. 


\section{Hasil dan Pembahasan}

Analisis dilakukan terhadap kondisi eksisting sistem sanitasi di Pondok Pesantren Al-Ittihad Kabupaten Cianjur Jawa Barat berdasarkan hasil penyebaran kuesioner. Pembahasan ini terbagi ke dalam beberap aspek yaitu sistem sarana air bersih di pesantren, sistem persampahan di pesentren, MCK, sarana air limbah dan perilaku sanitasi santri.

\section{Karakteristik Responden}

Karakteristik responden dalam penelitian ini terbagi dalam beberapa kategori, yaitu: tingkat pendidikan, usia dan lama tinggal di di Pondok Pesantren Al-Ittihad. Deskripsi mengenai profil responden penelitian peneliti jabarkan pada subbab di bawah ini:

\section{Tingkat Pendidikan}

Profil responden berdasarkan pendidikan dibagi menjadi tiga kategori, yakni santri Putri dari Sekolah Menengah Pertama (SMP), Sekolah Menengah Atas (SMA) dan Sekolah Menengah Kejuruan (SMK). Jumlah responden berdasarkan tinggkat pendidik dapat dilihat pada Gambar 1.

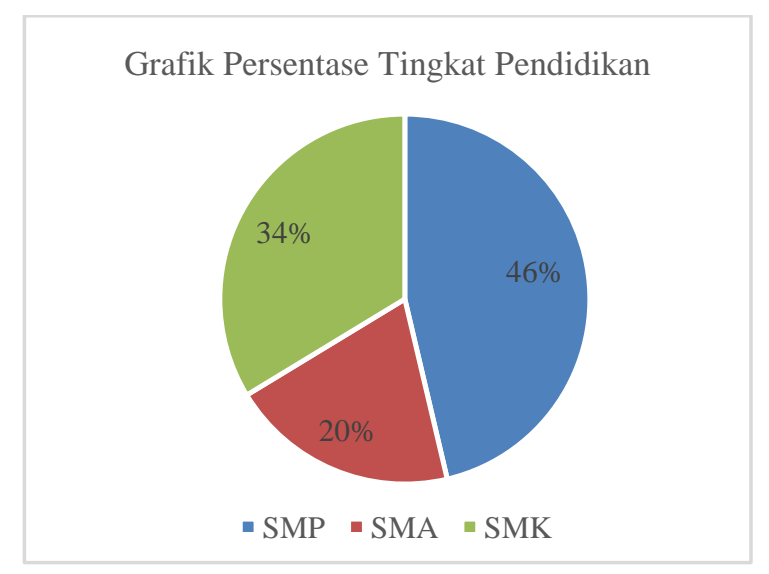

Gambar 1. Grafik Persentase Tingkat Pendidikan

Hasil perhitungan Slovin menunjukkan bahwa hampir separuh responden merupakan santri SMP sebesar 46\%, santri SMK sebesar $34 \%$ dan santri SMA sebesar $20 \%$.

\section{Usia Responden}

Target responden adalah santri putri di Pondok Pesantren Al-Ittihad dengan rata-rata rentan usia 13-15 tahun untuk santri putri SMP dan 16-19 tahun untuk santri putri SMA dan SMK. Persentase rentan usia responden dapat dilihat pada Gambar 2.

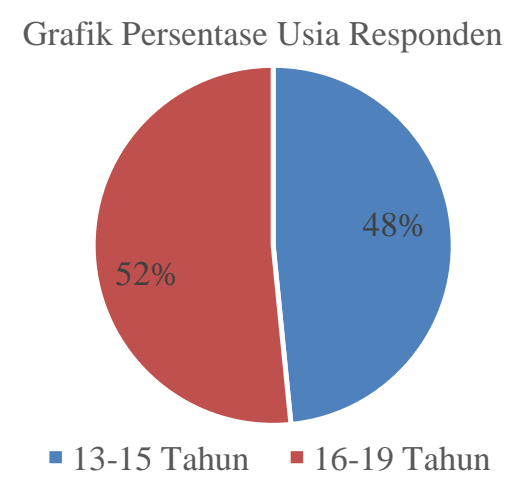

Gambar 2. Grafik Persentase Usia Responden

\section{Lama Tinggal di PondokPesantren}

Informasi lama tinggal di pondok pesantren dibutuhkan untuk melihat apakah semakin lama santri tinggal akan meningkatkan kepedulian mereka terhadap sanitasi di sekolah. Persentase lama tinggal santri dipesantren dapat dilihat pada Gambar 3.

Grafik Lama Tinggal di Pesantren

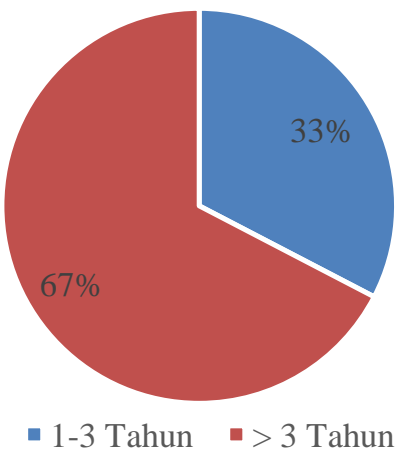

Gambar 3. Grafik Lama Tinggal di Pesantren 


\section{Sarana Air Bersih Pesantren}

Berikut penjelasan mengenai kondisi sarana Air Bersih di Pondok Pesantren Al-Ittihad dilihat berdasarkan hasil kuesioner.

\section{a. Kualitas dan Kuantitas Air Bersih}

Kualitas air yang baik dapat ditentukan dari segi warna, bau dan rasa. Untuk mengetahui kualitas air di pondok pesantren dilakukan kuesioner dengan hasil seperti pada Gambar 4.

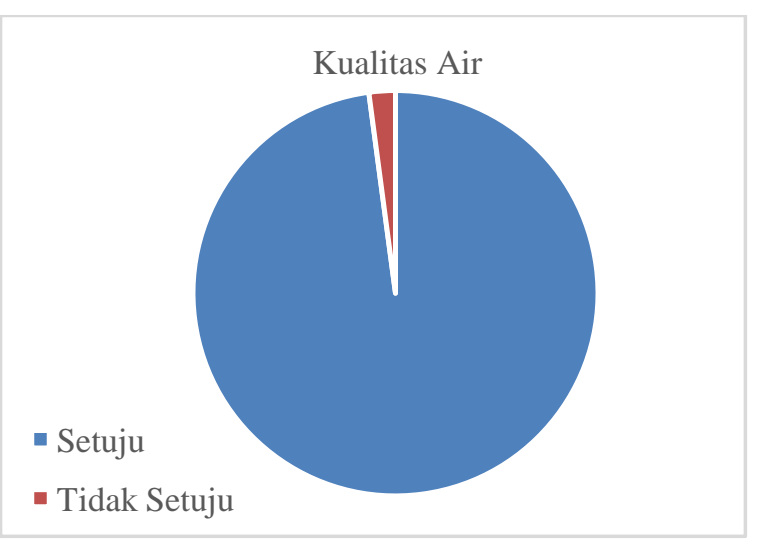

Gambar 4. Grafik Kualitas Air

Berdasarkan pada Gambar 4 dapat dilihat bahwa Pondok Pesantren Al-Ittihad memiliki kualitas fisik yang baik seperti tidak berbau, berasa dan berwarna. Hal ini sejalan dengan teori yang menyebutkan bahwa kualitas fisik air bersih yang dimanfaatkan oleh santri harus memenuhi syarat fisik air yaitu jernih, tidak berwarna, tidak berasa dan tidak berbau.

Berdasarkan Petunjuk Teknis Perencanaan Air Bersih dan PLP tahun 2002 perkiraan penggunaan air untuk type pesantren $\mathrm{D}$, yaitu pesantren dengan masjid, asrama, dan fasilitas pendidikan sebesar 95 - 120 L/orang/hari.

- Pada perhitungan ini digunakan perkiraan kebutuhan air santri sebanyak 95 L/orang/hari.

- Jumlah Santri putri $=1785$ orang

Maka kebutuhan air santri/hari adalah:

Kebutuhan Air $=$ Konsumsi air $\mathrm{x}$ Jumlah santri

$$
\begin{aligned}
& =95 \mathrm{~L} / \text { orang/hari } \times 1785 \text { orang } \\
& =169.575 \mathrm{~L} / \text { hari }
\end{aligned}
$$

Berdasarkan hasil perhitungan kebutuhan air di Pondok Pesantren Al-Ittihad sebesar 169.575 L/hari, untuk memenuhi kebutuhan air bersih sumber air yang digunakan adalah mata air yang jaraknya tidak jauh dari Pondok Pesantren AlIttihad, pemilihan sumber mata air di dasarkan dari kuantitasnya yang memenuhi dan kualitasnya yang baik.

\section{Sistem Sampah di Pesantren}

Beberapa aspek penting dalam sistem persampahan di pondok pesantren meliputi sistem pengelolaan sampah, wadah sampah, pemilahan sampah dan jumlah peratalan yang dibutuhkan untuk menujang pengelolaan sampah dari sumber hingga pengangkutan. Sampah merupakan sisa hasil kegiatan manusia seharihari manusia yang sudah tidak bisa dimanfaatkan lagi. Hal ini sejalan dengan penadapat para santri dimana mereka di beri kuesioner untuk menjawab bahwa sampah adalah sisa kegiatan sehari-hari manusia.

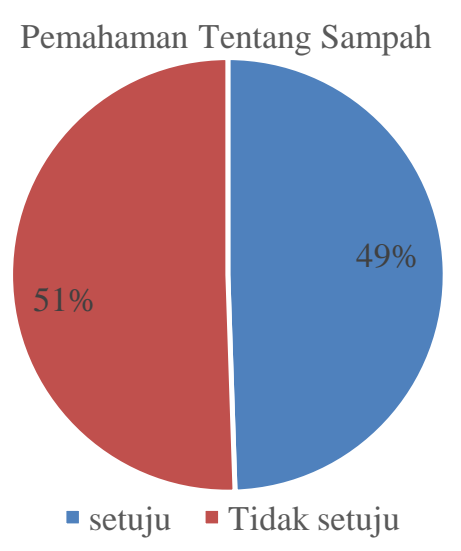

Gambar 5. Pemahaman Mengenai Sampah

Berdasarkan hasil kuesioner didapatkan hasil $51 \%$ santri setuju bahwa barang yang sudah tidak digunakan di katagorikan sebagai sampah dan dibuang.

Timbulan sampah di Pondok Pesantren AlIttihad berasal dari tiga kegiatan yaitu kegiatan belajar mengajar, asrama dan kantin. Gambar 6 
merupakan hasil sampling timbulan sampah yang dilakukan selama 3 hari.

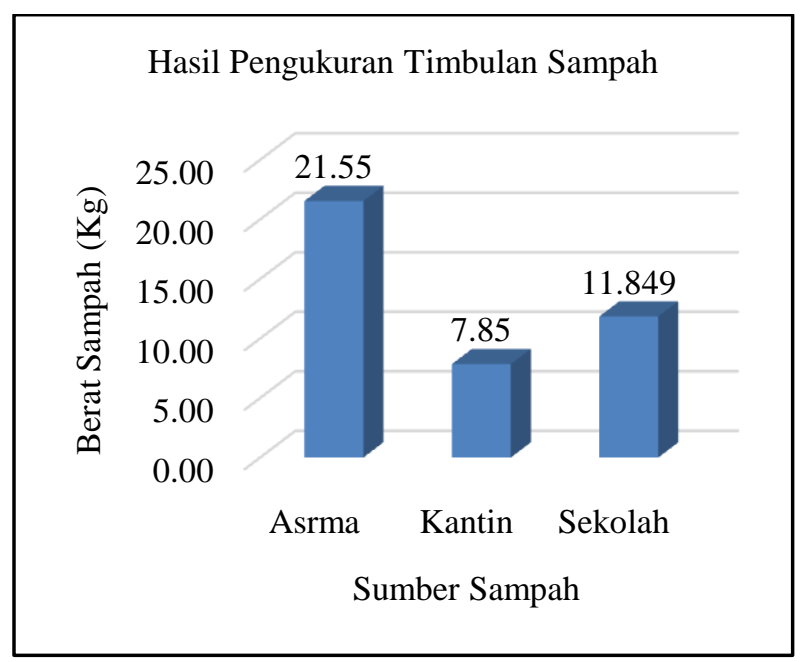

Gambar 6 Hasil Pengukuran Timbulan Sampah

Timbulan sampah terbanyak di Pondok Pesantren Al-Ittihad berasal dari kegiatan asrama sebesar $21,55 \mathrm{~kg}$, hal ini karena banyak kegiatan yang dilakukan di asrama dibandingkan dengan kegiatan sekolah dan kantin. Lebih dari setengah waktu dalam sehari kegiatan santri dihabiskan di asrama sehingga timbulan yang di hasilkan paling tinggi dibandingkan dari kantin dan sekolah.

- Timbulan Sampah

Timbulan sampah yang dihasilkan Pondok Pesantren Al-Ittihad adalah 2,75 L/orang /hari dan $26 \%$ merupakan sampah organik sehingga jumlah sampah organik yang dihasilkan sebesar 1,65 L/orang/hari.

Diasumsikan jumlah sampah organik yang dikomposkan adalah 30\% dari timbulan sampah organik yang dihasilkan sebesar 0,5 L/orang/hari atau $0,0005 \mathrm{~m}^{3} /$ orang/hari

- Kapasitas satu buah tong komposter $=\frac{1}{\mathbf{4}} \times \Pi \times{\text { diameter } \text { tong }^{2} \times \text { tinggi tong }}^{2}$ $=\frac{\mathbf{1}}{\mathbf{4}} \times \Pi \times(0,53 \mathrm{~m})^{2} \times 1 \mathrm{~m}=0,22 \mathrm{~m}^{3}$

- Volume sampah organik yang dapat dikomposkan $=0,0005 \mathrm{~m}^{3} /$ orang $/$ hari $\times 1785$ orang

$$
=0,89 \mathrm{~m}^{3} / \text { hari } \approx 0,9 \mathrm{~m}^{3} / \text { hari }
$$

Jika diasumsikan waktu detensi 15 hari

Volume total $=0,9 \mathrm{~m}^{3} /$ hari $\times 15$ hari

$$
=13,5 \mathrm{~m}^{3}
$$

- Menghitung Kebutuhan tong

$$
\begin{aligned}
& =\frac{\text { Volume total }}{\text { Kapasitas } 1 \text { tong }}=\frac{\mathbf{1 3 , 5} \mathbf{~ m}^{\mathbf{3}}}{\mathbf{0 , 2 2} \mathbf{~ m}^{\mathbf{3}}} \\
& =61,36 \approx 62 \text { buah tong. }
\end{aligned}
$$

Berdasarkan hasil perhitungan jumlah tong yang dibutuhkan sangatlah banyak, bila demikian reaktor dapat diganti menjadi rumah kompos sebanyak 1 unit dengan luas $13,5 \mathrm{~m}^{3}$.

\section{Ruang $M C K$}

Mandi, Cuci, Kakus (MCK) adalah aktifitas manusia yang dilakukan pada lokasi tertentu. Ruang MCK lebih banyak ditunjukan untuk meningkatkan kesejahteraan masyarakat dengan memperbaiki kondisi sanitasi di lingkungan pemukiman. Tabel 1 menyajikan hasil perhitungan kebutuhan MCK berdasarkan kapasitas layanan dan jumlah santri yang diambil dari Petunjuk Teknis Perencanaan Air Bersih dan PLP di Pondok Pesantren.

Tabel 1Perhitungan Kebutuhan MCK

\begin{tabular}{lccc}
\hline \multirow{2}{*}{$\begin{array}{c}\text { Jenis } \\
\text { Sarana/Dimensi }\end{array}$} & $\begin{array}{c}\mathbf{1 0 0} \\
\text { Santri } \\
\text { (Unit) }\end{array}$ & $\begin{array}{c}\text { Layanan } \\
\text { Santri } \\
\text { (Unit) }\end{array}$ & $\begin{array}{c}\mathbf{3 0 0 0} \\
\text { Santri } \\
\text { (Unit) }\end{array}$ \\
\hline Mandi $(1,7 \times 1,10) \mathrm{m}$ & 10 & 100 & 300 \\
Cuci $(1,00 \times 0,9) \mathrm{m}$ & 8 & 80 & 240 \\
Kakus $(1,40 \times 0,80) \mathrm{m}$ & 16 & 160 & 480 \\
Peturasan & 9 & 90 & 270 \\
Kran/Pancuran & 4 & 40 & 120 \\
\hline
\end{tabular}

Sumber: Petunjuk Teknis Pt-T-18-2002-C

\section{Ruang Mandi dan Kakus}

Ketersediaan antara ruang mandi dan kakus di Pondok Pesantren Al-Ittihad digabung peruntukannya. Jumlah ruang mandi yang berada dikawasan Asrama puteri memiliki total 137 unit, dan terbagi dalam beberapa titik bangunan, dengan kondisi dapat digunakan keseluruhannya. 
Jika mengacu kepada Petunjuk Teknis Perencanaan Air Bersih dan PLP di Pondok Pesantren jumlah ruang mandi di Pondok Pesantren Al-Ittihad tidak memuni standar dimana untuk 1785 santri hanya ada 137 kamar mandi, seharusnya terdapat 179 ruang mandi. Sehingga perlu direncanakan sebanyak 42 ruang mandi untuk mencukupi kebutuhan ruang mandi sesuai standar yang di tetapkan. Berdasarkan Petunjuk Teknis Perencanaan Air Bersih dan PLP di Pondok Pesantren dimensu ruang mandi yang direncanakan adalah Mandi $(1,7 \times 1,10) \mathrm{m}$.

- Perencanaan Konstruksi Kamar Mandi dan Kakus

Jumlah kamar mandi dan kakus yang direncanakan $=2$ bangunan dengan 42 ruang mandi dan kakus

Konstruksi pembuatan ruang mandi dan kakus $=1$ bangunan yang terdiri dari 21 ruang mandi.

Lama Konstruksi $=\frac{21 \text { ruang mandi }}{1 \text { tahun }}=2$ tahun

Sehingga untuk memenuhi kebutuhan ruang mandi dan kakus di Pondok Pesantren Al Ittihad diperlukan waktu 2 tahun jika dibangun 1 bangunan dengan 21 ruang mandi setiap tahunnya.

\section{Keran Wudhu dan Ruang Cuci}

Keran wudhu dan cuci merupakan fasilitas yang penting untuk menunjang kegiatan sehari hari santri di Pondok Pesantren Al-Ittihad, sehingga ketersediaanya perlu diperhatikan oleh pihak pesantren. Berdasarkan hasil observasi di lapangan Pondok Pesantren Al-Ittihad tidak memiliki ruang cuci khusus, dimana para santri mencuci hanya dari keran yang digabung dengan keran untuk wudhu, maka pada perencanaan kali ini akan di lakukan penetuan jumlah keran wudhu dan cuci.Berdasarkan hasil observasi kondisi eksisting pondok pesantren Al Ittihad memiliki 73 keran wudhu dan keran cuci dengan kondisi semua keran berfungsi dengan baik.
Menurut ketentuan Petunjuk Teknis Perencanaan Air Bersih dan PLP (Pt-T-182002-C) di Pondok Pesantren Departemen Pekerjaan Umum Direktorat Jendral Cipta Karya diperlukan 8 keran untuk 100 santri dengan jarak 1 meter setiap kerannya maka untuk 1785 santri perlu 144 keran. Untuk memenuhi kebutuhan keran wudhu dan keran cuci maka perlu ditambah sebanyak 71 keran.

\section{Penanganan Genangan Air}

Tidak adanya sistem penyerapan airdiPondok Pesantren Al Ittihad menyebabkan adanya genangan air setiap hujan turun, sehingga pada perencanaan ini akan dibuatkan sisitem penyerapan air menggunakan sistem biopori. Biopori adalah lubang-lubang kecil pada tanah yang terbentuk akibat akitifitas organisme di dalamnya, seperti cacing, perakaran tanaman, rayap, dan fauna tanah lainnya. Lubang tersebut akan berisi udara dan menjadi jalur mengalirnya air. Jadi air hujan tidak langsung masuk ke saluran pembuangan air, tetapi meresap ke dalam tanah melalui lubang tersebut. Bipori dibuat secara vertikal ke dalam tanah dengan diameter $10 \mathrm{~cm}$ dan kedalaman sekitar $100 \mathrm{~cm}$. Skema penampang lubang biopori dapat dilihat pada Gambar 7.

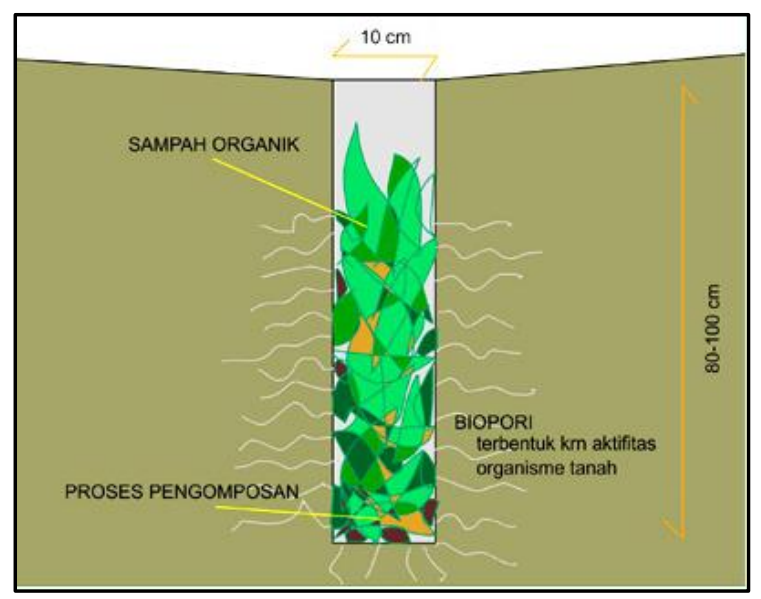

Gambar 7. Skema Penampang Lubang Biopori 
Berdasarkan data Badan Meteorologi dan Geofisika (BMKG) yang di kutip dari buletin informasi iklim Provinsi Jawa Barat prakiraan hujan bulan Februari, Maret dan April tahun 2018, intensitas curah hujan kabupaten cianjur berada pada intensitas sedang dengan nilai intensitas curah hujan $50 \mathrm{~mm} / \mathrm{jam}$, setelah didapat data curah hujan maka akan direncanakan jumlah lubang biopori yang akan dibuat sebagai berikut:

- Menghitung Jumlah Lubang Biopori

Intensitas Curah Hujan 50 mm/hari

Laju peresapan air 3 liter $/$ menit $=4320$

liter/hari

Luas bidang $=2000 \mathrm{~m}^{2}$

Maka jumlah lubang bipori,

Jumlah Lubang Biopori

$=\frac{\text { (Intensitas Curah Hujan } \mathrm{x} \text { Luas Bidang) }}{\text { Luas Peresapan Air }}$

$=\frac{50 \frac{\mathrm{mm}}{\mathrm{hari}} \times 2000 \mathrm{~m}^{2}}{4320 \text { liter /hari }}$

$=23,14 \approx 24$ lubang biopori

Bila lubang yang dibuat berdiameter $10 \mathrm{~cm}$ dengen kedalaman $100 \mathrm{~cm}$, maka setiap lubang dapat menampung 7,8 liter sampah organik. Ini berarti bahwa setiap lubang dapat diisi dengan sampah organik selama 2-3 hari. Dengan demikian 24 lubang baru dapat dipenuhi dengan sampah organik yang dihasilkan selama 48-72 hari. Dalam selang waktu tersebut lubang yang pertama diisi sudah terdekomposisi menjadi kompos sehingga volumenya telah menyusut. Dengan demikian lubang-lubang ini sudah dapat diisi kembali dengan sampah organik baru dan begitu seterusnya.

\section{Sistem Sarana Air Limbah}

Sistem pembuangan air limbah terbagi menjadi dua, yaitu air limbah kakus dan air limbah non kakus. Air limbah limbah kakus adalah yang berasal dari buangan biologis seperti kakus, berbentuk tinja manusia, maupun buangan lainnya berupa cairan ataupun buangan biologis, sedangkan air limbah non kakus adalah air limbah yang dihasilkan dari kegiatan sehari-hari seperti mandi dan mencuci. Untuk mengetahui sarana pembuangan air limbah di Pondok Pesantren Al-Ittihad maka dilakukan penyebaran kuesioner kepada pengelola pondok pesantren. Tabel berikut menampilkan sarana pembuangan air limbah.

Tabel 2. Sarana Pembuangan Air Limbah

\begin{tabular}{lc}
\hline \multicolumn{2}{c}{$\begin{array}{c}\text { Apakah ada saluran pembuangan air limbah } \\
\text { dari wc dan kamar mandi di pesantren ? }\end{array}$} \\
\hline $\begin{array}{l}\text { Ada, saluran } \\
\text { pembuangan air limbah } \\
\text { ke tangki septik. }\end{array}$ \\
\hline Ada, Saluran & Pembuangan dari WC \\
pembuangan air limbah & dapur, tempat cuci dan \\
ke sungai & air wudhu \\
\hline Tidak ada saluran air & - \\
\hline
\end{tabular}

Perencanaan penampungan air limbah kakus di Pondok pesantren Al Ittihad menggunakan tangki septik. Tangki septik adalah suatu ruangan yang berfungsi, menampung dan menggolah air limbah rumah tangga dengan kecepatan alir yang lambat, sehingga memberikesempatan untuk terjadi pengendapan terhadap suspensi benda-benda padat dan kesem-patan untuk penguraian bahan-bahan organik oleh jasad anaerobik membentuk bahanbahan larut air dan gas (SNI 03-2398-2002). Pada perencanaan ini akan dibuat tangki septik dengan dua kompartemen seperti pada Gambar 8 .

Asumsi seluruh buangan masuk kedalam tangki septik, baik dari WC, dapur, dll

$\mathrm{S}=40 \mathrm{1} / \mathrm{o} / \mathrm{th}:$ untuk timbulan dengan sumber WC, dapur,dll

Faktor Air Buangan $(\mathrm{fab})=80 \%=0,8$ 


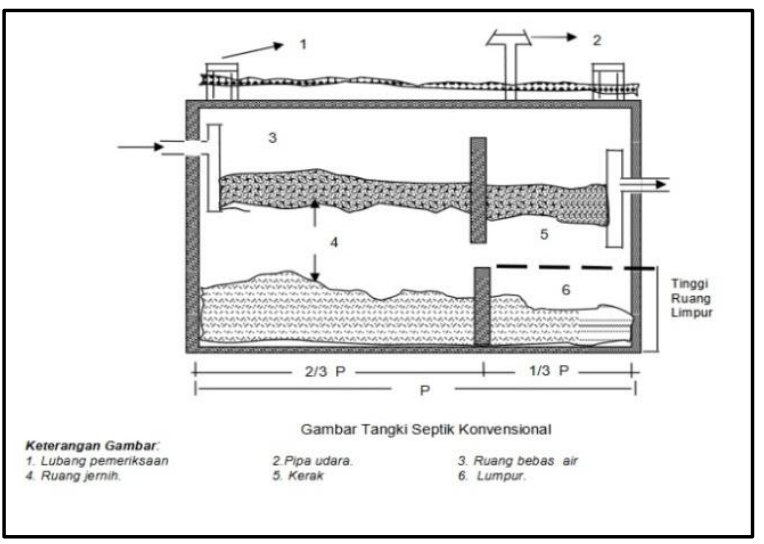

Gambar 8 Desain Tangki Septik

- Menghitung debit air bersih

Jumlah Santri $=1785$ santri

Debit Air Bersih = 95 L/Santri/hari $\times 1785$

Santri $=169.575 \mathrm{~L} / \mathrm{hari}$

- Menghitung minimum kapasitas yang dibutuhkan per hari

$\mathrm{A}=\mathrm{Q} a b \times f a b$

$=169.575 \mathrm{Lh} \times 0.8=135.660 \mathrm{l} / \mathrm{h}$

- Volume penampungan lumpur dan scum

$$
\mathrm{B}=\mathrm{P} \times \mathrm{N} \times \mathrm{F} \times \mathrm{S}
$$$$
=1785 \times 3 \times 1 \times 40 \mathrm{l} / \mathrm{o} / \mathrm{h}=214.200 \mathrm{l} / \mathrm{h}
$$

- Menghitung Total Volum Tangki Septik

$\mathrm{C}=\mathrm{A}+\mathrm{B}$

$\mathrm{C}=135.660 \mathrm{l} / \mathrm{h}+214.200 \mathrm{l} / \mathrm{h}=349.860 \mathrm{l} / \mathrm{h}$

$=349,86 \mathrm{~m}^{3} / \mathrm{h}$

Tinggi Tangki Septik $=1.5 \mathrm{~m}$

$\mathrm{Vol}=\mathrm{p} \times 1 \times \mathrm{T}$

$$
=10 \times 1,5 \mathrm{l}^{2}=152,66 \mathrm{~m}^{3}
$$

$1=\sqrt{\frac{349,86 \mathrm{~m}^{3}}{7,5}}=8,81 \mathrm{~m}$

Tabel 3. Ukuran Tangki Septik Komunal

\begin{tabular}{cccccc}
\hline \multicolumn{2}{c}{ Kompartemen Satu } & \multicolumn{3}{c}{ KompartemenDua } \\
\hline $\begin{array}{c}\text { Panjang } \\
(\mathbf{m})\end{array}$ & $\begin{array}{c}\text { Lebar } \\
(\mathbf{m})\end{array}$ & $\begin{array}{c}\text { Tinggi } \\
(\mathbf{m})\end{array}$ & $\begin{array}{c}\text { Panjang } \\
(\mathbf{m})\end{array}$ & $\begin{array}{c}\text { Lebar } \\
(\mathbf{m})\end{array}$ & $\begin{array}{c}\text { Tinggi } \\
(\mathbf{m})\end{array}$ \\
\hline 10 & 6,8 & 1.5 & 5 & 2,4 & 1.5 \\
\hline
\end{tabular}

\section{Kesimpulan}

Berdasarkan hasil observasi kondsi air bersih dan sanitasi di pondok pesantren Al Ittihad sudah cukup baik. Hasil penelitian menunjukkan bahwa secara kualitas, air bersih masih dapat diterima santri karena tidak berbau, tidak berasa dan tidak berwarna, namun secara kuantitas masih belum memenuhi dan perlu ditambah dari sumber air berupa mata air yang terletak di sekitar pesantren. Pengelolaan sampah belum optimal karena sampah organik belum dimanfaatkan. Jika kegiatan pengomposan dilakukan, maka perlu rumah pengomposan dengan luas $13,5 \mathrm{~m}^{3}$. Terdapat 137 ruang mandi yang disediakan untuk 1785 santri. Berdasarkan ketentuan dan perhitungan, jumlah MCK seharusnya minimal 179 ruang. Fasilitas dan teknologi lain yang perlu disediakan adalah lubang biopori untuk mengatasi genangan dan septic tank untuk mengolah air limbah.

\section{Daftar Pustaka}

Adriansyah, A. A. (2017). Keterkaitan antara Sanitasi Pondok Pesantren dengan Kejadian Penyakit yang Dialami Santri di Pondok Pesantren Sunan Drajat. Medical Technology and Public Health Journal, Vol 01 No 01: 4-13.

Pradana, M., \& Reventiary, A. (2016). Pengaruh Atribut Produk terhadap Keputusan Pembelian Sepatu Merek Customade (Studi di Merek Dagang Customade Indonesia). Jurnal Manajemen, Vol.6 No. 1: 1-10.

Sidhi, A. N., Raharjo, M., \& Dewant, N. A. (2016). Hubungan Kualitas Sanitasi Lingkungan dan Bakteriologis Air Bersih terhadap Kejadian Diare pada Balita di Wilayah Kerja Puskesmas Adiwerna Kabupaten Tegal. Jurnal Kesehatan Masyarakat, Vol 4, No 3: 665-676. 